\title{
THE ADOPTION AND FUNCTION OF INTERNATIONAL INSTRUMENTS: THOUGHTS ON TAIWAN'S ENACTMENT OF THE ACT TO IMPLEMENT THE ICCPR AND THE ICESCR
}

\author{
Mark L. Shope* \\ I. INTRODUCTION
}

The Charter of the United Nations (Charter) aims "to reaffirm faith in fundamental human rights, in the dignity and worth of the human person, in the equal rights of men and women and of nations large and small."1 The Charter goes on to state that the United Nations (UN) serves the purpose of "promoting and encouraging respect for human rights and for fundamental freedoms for all without distinction as to race, sex, language, or religion."2 These pronouncements were further expressed by the UN General Assembly in 1948 through the promulgation of the Universal Declaration of Human Rights. " accordance with the principles proclaimed in the Charter" and the Universal Declaration of Human Rights, the UN adopted the International Covenant on Civil and Political Rights (ICCPR) ${ }^{4}$ and the International Covenant on Economic, Social and Cultural Rights (ICESCR) ${ }^{5}$ on December 16, 1966.

Taiwan implemented into its domestic law the ICCPR and ICESCR (Covenants) on March 31, 2009, through the Act to Implement the International Covenant on Civil and Political Rights and the International Covenant on Economic, Social and Cultural Rights (Taiwan Act). ${ }^{6}$ Although Taiwan is not a

* J.D. Candidate, 2012, Indiana University Robert H. McKinney School of Law; LL.M., 2009, National Taiwan University College of Law; B.F.A., 1999, Carnegie Mellon University. The author can be contacted at markshope@gmail.com.

1. U.N. Charter pmbl.

2. Id. art. 1 .

3. Universal Declaration of Human Rights, G.A. Res. 217 (III) A, U.N. Doc. A/RES/217(III) (Dec. 10, 1948) [hereinafter UDHR].

4. International Covenant on Civil and Political Rights, Dec. 16, 1966, 999 U.N.T.S. 171 [hereinafter ICCPR]. The ICCPR was adopted by consensus through the United Nations General Assembly Resolution 2200A (XXI); it entered into force on March 23, 1976.

5. International Covenant on Economic, Social and Cultural Rights, Dec. 16, 1966, 993 U.N.T.S. 3 [hereinafter ICESCR]. Adopted through the United Nations General Assembly resolution 2200A (XXI). The ICESCR entered into force on January 3, 1976.

6. Gongmin yu Zhengzhi Quanli Guoji Gongyue ji Jingji Shehui Wenhua Quanli Guoji Gongyue Shixing Fa (公民與政治權利國際公約及經濟社會文化權利國際公約施行法) [Act to Implement the International Covenant on Civil and Political Rights and the International Covenant on Economic, Social and Cultural Rights], art. 1 (promulgated Apr. 22, 2009), Laws \& Regulations Database of the Republic of China, MINISTRY OF JUSTICE, http://mojlaw.moj.gov.tw/EngLawContent.aspx?id=3 (Taiwan) [hereinafter Taiwan Act]. Other 
member of the UN and, therefore, cannot formally be a member of the Covenants, Taiwan implemented the Covenant provisions with the ultimate goal of strengthening its human rights protection system. ${ }^{7}$ Taiwan highly respects the human rights of its citizens, and demand for this respect is growing. ${ }^{8}$ But real human rights problems, such as corruption, discrimination against women, human trafficking, and abuse of foreign migrant workers, still exist in Taiwan and need to be addressed. ${ }^{9}$ The implementation of the ICCPR and ICESCR into Taiwan's domestic law has afforded Taiwan a brilliant opportunity and an additional mechanism for holding itself accountable for its human rights issues. ${ }^{10}$ Taiwan's human rights situation will likely be strengthened by the fruitful and constructive dialogue among the government, non-governmental organizations (NGOs), and other stakeholders that is encouraged by the Covenants. ${ }^{11}$ This dialogue can be facilitated in part by the formation of ad hoc committees that provide recommendations for the future development of human rights guarantees. ${ }^{12}$ Additionally, the Covenants promote the tweaking of domestic law to conform to Covenant provisions and hearten a passionate effort by States parties and NGOs to report on measures taken to implement their human rights protections. ${ }^{13}$ The next four years are crucial for determining Taiwan's level of commitment to the ICCPR and ICESCR. ${ }^{14}$

This Note discusses two major themes that have emerged from Taiwan's ratification of the Covenants. The first regards the salient meaning and implications of ratification and non-membership of international treaties along

relevant legal information is provided by Taiwan Law Resources. See TAIWAN LAW RESOURCES, www.taiwanlawresources.com (last visited Jan. 14, 2012).

7. Taiwan Act, supra note 6, art. 1.

8. See generally Wen-Chen Chang, An Isolated Nation with Global-Minded Citizens: Bottom-up Transnational Constitutionalism in Taiwan, 4 NAT'L TAIWAN U. L. REV. 203 (2009).

9. Bureau of Democracy, Human Rights, and Labor, 2008 Human Rights Reports: Taiwan, U.S. DEP'T STATE (Feb. 25, 2009), http://www.state.gov/g/drl/rls/hrrpt /2008/eap/119038.htm.

10. An opportunity for Taiwan's accountability to international human rights norms also occurred with its implementation of the Convention on the Elimination of All Forms of Discrimination against Women (CEDAW). See infra Part V.A.

11. See U.N. Office of the High Comm'r for Human Rights, Manual on Human Rights Reporting Under Six Major International Human Rights Instruments, at 262, U.N. Doc. HR/PUB/91/1 (Rev.1) (1997) [hereinafter Manual] ("The main function of the Committee is to assist States Parties in fulfilling their obligations under the Covenant, to make available to them the experience the Committee has acquired in its examination of other reports and to discuss with them any issue related to the enjoyment of the rights enshrined in the Covenant in a particular country.").

12. See infra Part VI.

13. Id.

14. This time frame takes into account the time necessary for Taiwan to make its domestic law conform to the Covenants and gives the Government and civil society time to complete one initial reporting cycle. See infra Figures 1, 2. 
with the judicial adoption and the function of these international instruments. ${ }^{15}$ This salience derives from the fact that Taiwan is not a member of the UN and, in general, cannot be a member of the Covenants. ${ }^{16}$ At the same time, Taiwan has chosen to implement the ICCPR and ICESCR into its domestic law, leaving open the issue of these instruments' legal status in domestic law and courts. ${ }^{17}$ The second theme is how and to what extent Taiwan, through both its government and civil society actors, plans to fulfill the duties embodied by the Covenants and ensure its accountability for those obligations. ${ }^{18}$ To this end, the discussion in this Note is founded on Articles 5 and 6 of the Taiwan Act as they relate to the Covenants. Article 5 states that " $[\mathrm{t}] \mathrm{he}$ government should cooperate with other national governments and international non-governmental organizations and human rights institutions to realize promotion and protection of human rights provisions in the two Covenants."19 Article 6 states that " $[t]$ he government should set up human rights reports system in accordance with the two Covenants.",20

Specifically, this Note begins with a discussion of the rights embodied in the Covenants and briefly discusses their relation to Taiwan's constitutional and legislative guarantees of civil, political, economic, social, and cultural rights. ${ }^{21}$ Further discussion includes the challenges of international human rights law in Taiwan and the judicial adoption and the function of international human rights law from both a monist and a dualist point of view. ${ }^{22}$ This Note also discusses the meaning and implications of ratification and non-membership of an international treaty and suggests that Taiwan implement the reporting obligations established by Article 40 of the ICCPR and Article 16 of the ICESCR. ${ }^{23}$ Along with an overview of this State reporting process, this Note discusses an "alternative" NGO reporting process. ${ }^{24}$ It gives humble, yet

15. See infra Parts II.B, III.

16. This Note will not discuss political issues regarding Taiwan's sovereignty. "Under precedent both de jure and de facto sovereignty are political questions-indeed, archetypal political questions." Lin v. United States, 561 F.3d 502, 507 (D.C. Cir. 2009). Human rights, on the other hand, "are based on what are assumed to be the permanent characteristics of human nature" and not transient political issues. K. Lee Boyd, Are Human Rights Political Questions?, 53 RUTGERS L. REv. 277, 308 (2001). Issues surrounding membership in the Covenants and being bound by the Covenants are distinguished and discussed below. See infra Parts II, III.

17. There have been changes to domestic law, but there are still laws that have yet to be amended. See The Judicial Yuan Reviews Regulations in Response to the Promulgations of the Covenants; It also Promotes Legislation on Speedy and Fair Trials, JUD. YUAN (Nov. 5, 2009) [hereinafter Response to the Promulgations], available at http://jirs.judicial.gov.tw/ GNNWS/engcontent. asp?id=36952\&MuchInfo $=1$.

18. See infra Parts IV, V.

19. Taiwan Act, supra note 6, art. 5 .

20. Id. art. 6.

21. See infra Part I.A-C.

22. See infra Part II.

23. See infra Parts III, IV.B-C.

24. See infra Parts IV, V. 
comprehensive suggestions for the mechanics of the Taiwanese government's reporting obligations under the Covenants, Taiwanese NGOs' participation in this process, and the makeup of the ad hoc committee on human rights and economic, social and cultural rights. ${ }^{25}$ This Note concludes with remarks regarding the future of treaty implementation in Taiwan. ${ }^{26}$

Since Taiwan is not an official member of the UN, participation in international fora is difficult, but it is not impossible. ${ }^{27}$ Taiwan has experience participating with the international community through non-governmental entities as well as ad hoc bodies that have an international nature. ${ }^{28}$ This Note takes the point of view that Taiwan will be able to accomplish the tasks of conforming its domestic law to the Covenants while holding itself accountable to the Covenant provisions through ad hoc committees made up of international actors. ${ }^{29}$

\section{A. Background of the Covenants}

There exists a variety of human rights, which can be categorized in a myriad of ways. ${ }^{30}$ The current trend, however, is to classify human rights as either civil and political rights or economic, social, and cultural rights. ${ }^{31}$ In 1997 the Office of the High Commissioner for Human Rights, the UN Institute for Training and Research, and the UN Staff College Project published a Manual on Human Rights Reporting, which explains the birth of the Covenants as follows:

The Universal Declaration of Human Rights comprises these two major categories of human rights in one document. However, when the other component parts of the International Bill of Human Rights were elaborated, it was decided to split these two categories of human rights into two separate documents, an International Covenant on Civil and Political Rights, and an International Covenant on Economic, Social and Cultural Rights. The rationale for this division was that the two sets of rights differed in nature-one category of rights was subject to immediate application, whereas the other

25. See infra Parts VI, VII.

26. See infra Part VII.

27. Taiwan was able to participate as an observer in the 62nd World Health Assembly in May, 2009. Che-ming Yang, The Road to Observer Status in the World Health Assembly: Lessons from Taiwan's Long Journey, 5 ASIAN J. WTO \& INT'L HEALTH L. \& POL'Y 331, 331 (2010).

28. See infra Part IV.

29. See infra Part V.

30. Manual, supra note 11 , at 5 .

31. Id. 
category required progressive realization-and therefore different implementation measures were called for. ${ }^{32}$

Notwithstanding the popular distinction between these human rights categories, the UN has emphasized the indivisibility and interdependence of all human rights, ${ }^{33}$ it has also emphasized that these rights must first be implemented at national and local levels. ${ }^{34}$

\section{B. ICCPR Rights and Civil and Political Rights Embodied in the Constitution of Taiwan}

The Office of the UN High Commissioner for Human Rights (High Commissioner for Human Rights) describes the ICCPR as elaborating "the civil and political rights set out in the [Universal Declaration of Human Rights]. ${ }^{, 35}$ That Covenant incorporates key civil and political rights and freedoms, ${ }^{36}$ and it also requires States to report periodically to the Human Rights Committee. ${ }^{37}$

Civil and political rights can be found generally throughout the Constitution of the Republic of China (Taiwan) (Constitution of Taiwan) but specifically in Chapter II, Rights and Duties of the People, ${ }^{38}$ and Chapter XIII, Fundamental National Policies. ${ }^{39}$ Some civil and political rights can also be found in Article 10 of the Additional Articles of the Constitution of the Republic of China (Taiwan) (Additional Articles). ${ }^{40}$

C. ICESCR Rights and Economic, Social, and Cultural Rights Embodied in the Constitution of Taiwan

The High Commissioner for Human Rights describes the ICESCR as developing "the corresponding rights in the Universal Declaration [of Human Rights] in considerable detail, specifying the steps required for their full realization. ${ }^{, 41}$ Thus, the ICESCR elaborates on the right to education, health,

32. Id.

33. Id. at 6 .

34. Id. at 8,16 .

35. Office of the U.N. High Comm'r for Human Rights, The United Nations Human Rights Treaty System: An Introduction to the Core Human Rights Treaties and the Treaty Bodies 7, Fact Sheet No. 30 (June 2005), http://www.unhcr.org/refworld/docid/479477490.html [hereinafter Factsheet No. 30].

36. Id.

37. Id.

38. See Zhonghua Minguo Xianfa [Minguo Xianfa] [The Constitution of the REPUBLIC OF CHINA] ch. II (1947) (Taiwan).

39. See id. ch. XIII.

40. Zhonghua Minguo Xianfa Zhengxiu Tiaowen [Zhengxiu Tiaowen] [Additional ARTICLES OF THE CONSTITUTION OF THE REPUBLIC OF CHINA] art. 10 (2005) (Taiwan).

41. Factsheet No. 30, supra note 35 , at 8 . 
and work, using the Universal Declaration of Human Rights as a model and sometimes mirroring its specific language. ${ }^{42}$ Part IV of this Covenant, like the ICCPR, requires periodic reporting by States parties. ${ }^{43}$ The Human Rights Council created the Committee on Economic, Social and Cultural Rights (CESCR) to carry out these monitoring activities. ${ }^{44}$ One notable difference between the two Covenants is

the principle of progressive realization in Part II of the [ICESCR]. Article 2(1) specifies that a State party "undertakes to take steps, [...] to the maximum of its available resources, with a view to achieving progressively the full realization of the rights recognized in [the Covenant]." The principle of progressive realization acknowledges the constraints States parties may face due to the limits of available resources. ${ }^{45}$

The ICCPR does not recognize such progressive realization.

Relevant social, economic, and cultural rights can be found throughout the Constitution of Taiwan and are further enumerated in Article 10 of the Additional Articles. ${ }^{46}$ Article 10 guarantees the promotion of universal health insurance and encourages "research and development of both modern and traditional medicines." ${ }^{, 47}$ also safeguards the dignity of women by promoting the elimination of sexual discrimination and gender inequality, ${ }^{48}$ and it guarantees the allocation of social resources to physically and mentally handicapped persons. ${ }^{49}$ In addition, Article 10 emphasizes the need for social welfare services, funding for education, science, and culture ${ }^{50}$ Further, Article 10 recognizes the need to preserve and develop aboriginal cultures, ${ }^{51}$ guarantees ethnic cultures' political participation, and provides assistance and encouragement for their education, culture, transportation, water conservation, health and medical care, economic activity, land, and social welfare. ${ }^{52}$ Significantly, all Article 10 guarantees are practiced and promoted in Taiwan, not just enunciated on paper. ${ }^{53}$

42. Id.

43. See infra Part IV.B.

44. Factsheet No. 30, supra note 35, at 9 .

45. Id. (citations omitted).

46. See generally ZHENGXIU TIAOWEN.

47. Id. art. 10 , para. 5 .

48. Id. para. 6.

49. Id. para. 7. These protections include the guarantee of an obstacle-free environment. Id.

50. Id. para. 8.

51. Id. para. 12.

52. Id.

53. See International Covenant on Economic, Social and Cultural Rights - Its Value and Stipulations on Human Rights, MINISTRY OF JUSTICE, http://www.moj.gov.tw/ct.asp?xItem= $154750 \& \mathrm{ctNode}=11387 \& \mathrm{mp}=095$ (last updated Apr. 10, 2009) ("The enactment of the law of 


\section{ADOPTION OF THE ICCPR AND ICESCR: THE CHALLENGES OF INTERNATIONAL HUMAN RIGHTS LAW IN TAIWAN}

\section{A. Introduction}

Throughout history, Taiwanese culture has been significantly influenced by various parts of the world. ${ }^{54}$ Taiwan has been a European possession (16241661 ), a kingdom (1661-1683), a prefecture (1684-1885), a province (1885$1895)$, a colony (1895-1945), and a province once again (1945-1949). ${ }^{55}$ Recently, Taiwan was claimed as a province by the People's Republic of China (PRC), but it has never been under PRC control. ${ }^{56}$ From 1949 to 1991, Taiwan was the only province effectively controlled by the Republic of China (ROC), even though the ROC claimed control over all of China's territories. ${ }^{57}$ Finally, in 1991 the ROC claimed that its effective control was limited to Taiwan, Penghu, Jinmen, and Mazu. ${ }^{58}$

Although the dominion labels placed on Taiwan have been disputed throughout history, ${ }^{59}$ it is of ultimate importance for domestic implementation of international human rights norms that, despite so-called regime changes and portions of history where state institutions have been particularly oppressive, Taiwan has remained largely in charge of its own affairs. ${ }^{60}$ As such, years of struggle have yielded a strong democratic government system in Taiwan. ${ }^{61}$ Its justice system has independent courts, judges, prosecutors, and lawyers, ${ }^{62}$ and there is a thriving, well-established, and deeply-rooted legal education system; one with internationally respected scholars and a bar that is strong and ethical. ${ }^{63}$ The Constitution of Taiwan guarantees basic human rights and emphasizes rule

enforcement represents Taiwan's embracement of the two covenants, which is helpful to Taiwan in its promotion of human rights and in its effort to establish [a] link with the international system. In compliance with the President's instruction, the Ministry of Justice has worked out a plan for enforcing the two covenants.").

54. See generally DENNY RoY, TAIWAN: A POLITICAL HISTORY xi-xiii (2002).

55. See generally id. at 11-76.

56. See generally id. at 76-105.

57. Id. at $81-82,152$.

58. Id. at 184 .

59. See Mark Harrison, Legitimacy, Meaning and Knowledge IN the Making of TAIWANESE IDENTITY 5 (1 st ed. 2006) (discussing identity issues in Taiwan).

60. See Mark Shope, On the Taiwanese Identity as Shaped by the Development of Its Legal System (2009) (unpublished LL.M. thesis, National Taiwan University College of Law) (on file with National Taiwan University Library, National Taiwan University).

61. MiNGUO XIANFA art. 1 (1947) (Taiwan) (noting that Taiwan is "a democratic republic of the people to be governed by the people and for the people").

62. See id. art. 80 ("Judges shall be above partisanship and shall, in accordance with law, hold trials independently, free from any interference.").

63. See Zhonghua Minguo LÜSHI GONGHUI QUANGUO LianheHUI (中華民國律師公會全國聯合會) [TAIWAN BAR Ass'N], http://www.twba.org.tw/index.asp (last visited Jan. 14, 2012). 
of law and democracy. ${ }^{64}$ It also has a mechanism for constitutional review through the Council of Grand Justices. ${ }^{65}$ Taiwan further has a strong consumer protection framework, robust property laws, ${ }^{66}$ and laws aimed at preventing domestic violence and maintaining equality among the sexes. ${ }^{67}$ In addition, civil dispute resolutions in Taiwan are in keeping with international practice, and there is an arbitration mediation system that is international in character. ${ }^{68}$ Taiwanese labor protection laws also are very strong, and the criminal code and code of criminal procedure maintain high standards of human dignity and are transparent and fair. ${ }^{69}$

The passing of the Taiwan Act is simply a natural consequence of Taiwan's democratic system, which places a great deal of emphasis on the rights of its citizens. These protections have arisen through domestic legislation, but special situations arise when governments are limited in entering into agreements with other governments but want to strengthen their domestic commitments with international instruments. ${ }^{70}$

\section{B. Judicial Adoption and Function of International Human Rights Law}

There exist two very basic theories regarding the relationship between international and domestic law: monism and dualism..$^{71}$ The monist view holds that international law and domestic law function as the same legal system, meaning domestic courts may employ international law in making decisions. ${ }^{72}$ The dualist view holds that international law and domestic law exist separately; therefore, domestic courts may incorporate or reject international principles at their discretion. ${ }^{73}$ One commentator, Melissa A. Waters, has discussed the incorporation of human rights treaties into domestic law in light of these two

64. See Minguo XIANFA (1947) (Taiwan); see supra notes 41-53 and accompanying text..

65. Justices of the Constitutional Court, JUD. YUAN, http://www.judicial.gov.tw/constitutionalcourt/ EN/p01_03.asp (last visited Jan. 14, 2012).

66. Xiaofeizhe Baohu Fa (消費者保護法) [Consumer Protection Law] (amended Feb. 5, 2005) (Taiwan); Minfa (民法) [Civil code] (amended May 26, 2010) (Taiwan).

67. Jiating Baoli Fangzhi Fa (家庭暴力防治法) [Domestic Violence Prevention Act] (amended Apr. 29, 2009) (Taiwan); Xingbie Gongzuo Pingdeng Fa (性別工作平等法) [Gender Equality in Employment Act] (amended Jan. 5, 2011) (Taiwan); Xingbie Pingdeng Jiaoyu Fa (性別本等教育法) [Gender Equity in Education Act] (amended May 26, 2010) (Taiwan).

68. Minshi Susong Fa (民事訴訟法) [Code of Civil Procedure] (amended July 8, 2009) (Taiwan); Zhongcai Fa (仲裁法) [Arbitration Law] (amended Dec. 30, 2009) (Taiwan).

69. Zhonghua Minguo Xingfa (中華民國刑法) [Criminal Code] (amended Jan. 26, 2011) (Taiwan); Xingshi Susong Fa (刑事訴訟法) [The Code Of Criminal Procedure] (promulgated July 28, 1928, amended June 23, 2010) (Taiwan).

70. See supra note 16 and accompanying text.

71. John F. Coyle, Incorporative Statutes and the Borrowed Treaty Rule, 50 VA. J. INT'LL. 655, 656, n.1 (2010); Jonathan Turley, Dualistic Values in the Age of International Legisprudence, 44 HASTINGS L.J. 185, 201 (1993).

72. Coyle, supra note 71.

73. Turley, supra note 71. 
theories. ${ }^{74}$ Waters advocates a "narrow lens approach" that focuses on exploring the variety of techniques that enable courts to utilize a particular international source in interpreting domestic law. ${ }^{75}$ In areas with a civil law tradition, international instruments, such as human rights treaties, are often "automatically" incorporated into domestic law. ${ }^{76}$ The reason for automatic incorporation of these instruments is that there is less of a distinction between international and domestic law, in part because they have the same natural law source. ${ }^{77}$ Consequently, when governments from civil law traditions such as Taiwan ${ }^{78}$ refer to international treaties, ${ }^{79}$ they act perfectly in line with their legal tradition. ${ }^{80}$ Giving treaties a higher normative status than that given to ordinary national legislation is not a new phenomenon. ${ }^{81}$ Indeed, some States have given human rights treaties a normative rank higher than that of other treaties. $^{82}$

Regarding monist and dualist viewpoints, Article 2 of the Taiwan Act states that the "[h]uman rights protection provisions in the two Covenants have domestic legal status" (guoneifa de xiaoli). ${ }^{83}$ Thus, not only do the Covenants have domestic legal status because of the civil law monist approach, but Taiwan has explicitly given these Covenants domestic legal status through the Taiwan Act.

\section{Use of International Instruments as Aids in Interpreting the Constitutionality of National Legislation - A Judicial Point of View}

As of January 14, 2012, the Constitutional Court of the Republic of China (Taiwan) (Constitutional Court) had rendered 695 Interpretations. ${ }^{84}$ The

74. Melissa A. Waters, Creeping Monism: The Judicial Trend Toward Interpretive Incorporation of Human Rights Treaties, 107 COLUM. L. REv. 628, 628 (2007).

75. Id. at 632 .

76. Id. at 641 .

77. Id. (noting that civil law countries are monist in nature).

78. Andrew Jen-Guang Lin, Common Law Influences in Private Law - Taiwan's Experiences Related to Corporate Law, 4 NaT'L TAIWAN U. L. REv. 107, 132 (2009) ("Taiwan is a civil law country. However, common law rules, particularly those developed from the U.S. courts, have significant influences on Taiwan's private law."). See also Tay-sheng Wang, The Legal Development of Taiwan in the 20th Century: Toward a Liberal and Democratic Country, 11 PAC. RIM L. \& POL'Y J. 531, 531-39 (2002).

79. "Refer" in this sense is interpreted broadly to also mean, inter alia, ratify, accept, approve, assent, and consent. See Vienna Convention on the Law of Treaties art. 2, para. 1(b), May 23, 1969, 1155 U.N.T.S. 331 [hereinafter VCLT].

80. Waters, supra note 74 , at 641 .

81. Id.; Thomas Buergenthal, Modern Constitutions and Human Rights Treaties, 36 Colum. J. TRANSNAT'L L. 211, 215 (1997).

82. Buergenthal, supra note 81 , at 217.

83. Taiwan Act, supra note 6 , art. 2.

84. See Interpretations, Justices of the Constitutional Court, JUD. YUAN, http://www.judicial.gov.tw/ constitutionalcourt/en/p03.asp (last visited Jan. 14, 2012). Article 
Constitutional Court began referring to international human rights laws in the $1990 \mathrm{~s},{ }^{85}$ and in total, the Court has referred to international treaties in seven majority opinions and eighteen separate opinions. ${ }^{86}$ So far, Taiwan has taken a limited approach to incorporating international law into these interpretations; however, when the judges of the Constitutional Court have made reference to international instruments, their stance has been very strict. ${ }^{87}$

The Bangalore Principles of Judicial Conduct require judges to stay "informed about relevant developments of international law, including international conventions and other instruments establishing human rights norms. ${ }^{, 88}$ This principle is listed under Value 6, regarding competence. ${ }^{89}$ This means knowledge of these international norms is necessary for a judge to be competent, but that a judge is not necessarily required to refer to such instruments. ${ }^{90}$ But since the Constitutional Court began referring to international laws in the 1990s, judges in Taiwan have been living up to the international norms embodied in the Bangalore Principles and have been adopting the monist tradition of incorporating international law. ${ }^{91}$

Importantly, the Constitutional Court has not only referenced international treaties in its opinions, it has also utilized these treaties to interpret the meaning of certain domestic legal concepts. ${ }^{92}$ For instance, Interpretation 392 states, "In light of the abovementioned international conventions, it is obvious that the prosecutor shall not have the detention power enumerated in the Code of Criminal Procedure. ${ }^{, 93}$ In Interpretation 549, the Justices similarly held that "an overall examination and arrangement, regarding the survivor allowance, insurance benefits and other relevant matters, should be conducted

78 of the Constitution states that "[ $[$ ] he Judicial Yuan shall interpret the Constitution and shall have the power to unify the interpretation of laws and orders." MiNGUO XIANFA art. 78. For more information regarding Constitutional review in Taiwan, see Nuno Garoupa et al., Explaining Constitutional Review in New Democracies: The Case of Taiwan, 20 PAC. RIM L. \& POL'Y J. 1 (2011).

85. Chang, supra note 8 , at 212 .

86. See id. (referring to Interpretations No. 372 (Feb. 24, 1995), No. 392 (Dec. 22, 1995), No. 549 (Aug. 2, 2002), No. 578 (May 21, 2004), No. 582 (Sept. 23, 2004), No. 587 (Dec. 30, 2004), No. 623 (Jan. 26, 2007), the CRC, ICCPR, ECHR, ACHR, International Labor Conventions, and the UDHR).

87. See infra notes $92-103$ and accompanying text.

88. BANGALORE PRINCIPLES OF JUDICIAL CONDUCT art. 6.4, U.N.E.S.C. Res. 2006/23 (2002) [hereinafter BANGALORE PRINCIPLES] (adopted by the Judicial Group on Strengthening Judicial Integrity, as revised at the Round Table Meeting of Chief Justices held at the Peace Palace, The Hague, Nov. 25-26, 2002).

89. Id. Value 6.

90. See id. Value 6.

91. See supra Part II.B.

92. See, e.g., J.Y. Interpretation No. 392 (Dec. 22, 1995).

93. Id. (Referencing the European Convention for the Protection of Human Rights and Fundamental Freedoms, the International Convention for Citizens and their Political Rights, the Continental American Human Rights Convention, and a European Court of Human Rights decision.). 
in accordance with the principles of this Interpretation, international labor conventions and the pension plan of the social security system." ${ }^{.94}$ Likewise, Interpretation 578 states, "The provisions of international labor conventions... shall also be taken into account." ${ }^{\text {"95 }}$ Although the Constitutional Court has not used international instruments frequently, the instruments have clearly been given great deference, to the level of being heavily influential on the outcome of an interpretation. ${ }^{96}$ Accordingly, reference to international treaties by the Taiwanese courts is perfectly congruent with the precepts of Taiwan's legal tradition. ${ }^{97}$ By stating that "[ $\left.\mathrm{h}\right]$ uman rights protection provisions in the two Covenants have domestic legal status," Article 2 of the Taiwan Act simply reinforces the fact that these international instruments will be given equal or possibly higher normative status than ordinary national legislation. ${ }^{98}$

To fulfill the Taiwan Act's desire to strengthen Taiwan's human rights protection system, the Judicial Yuan (the highest judicial organ of Taiwan), in addition to incorporating international instruments into court Interpretations, has drafted legislation to harmonize Taiwan laws with the Taiwan Act. ${ }^{99}$ This includes the Act for Speedy and Fair Criminal Trials, many provisions of the Code of Criminal Procedure, and the Law Governing the Disposition of Juvenile Case ${ }^{100}$ In addition, the Judicial Yuan established a task force to research amending the Compulsory Execution Act, ${ }^{101}$ and amendments are planned for the Legal Aids Act as well. ${ }^{102}$ If Taiwan, like other civil law countries, takes the monist view, the ICCPR, ICESCR, and domestic law will continue to function as the same legal body currently available to the Constitutional Court. ${ }^{103}$

\section{Overriding Rights in the ICCPR and ICESCR and the Monist and Dualist Theories - Legislative Point of View}

While civil law traditions grant higher normative status to human rights

94. J.Y. Interpretation No. 549 (Aug. 2, 2002) (emphasis added).

95. J.Y. Interpretation No. 578 (May 24, 2004) (emphasis added).

96. Id.

97. Waters, supra note 74 , at 641 .

98. Taiwan Act, supra note 6, art. 2.

99. Id. art. 1; Response to the Promulgations, supra note 17.

100. Response to the Promulgations, supra note 17; Xingshi Tuosu Shenpan Fa (刑事妥速審判法) [Act for Speedy and Fair Criminal Trials] (promulgated May 19, 2010) (Taiwan); Xingshi Susong Fa (刑事訴訟法) [The Code Of Criminal Procedure] (promulgated July 28, 1928, amended June 23, 2010) (Taiwan); Shaonian Shijian Chuli Fa (少年事件處理法) [Law Governing the Disposition of Juvenile Cases] (promulgated May 18, 2005) (Taiwan).

101. Id.; Qiangzhi Zhixing Fa (強制執行法) [Compulsory Execution Act] (amended June 29, 2011) (Taiwan).

102. Id.; Falü Fuzhu Fa (法律扶助法) [Legal Aid Act] (amended Dec. 30, 2009) (Taiwan).

103. See Coyle, supra note 71 , at 656, n. 1 . 
treaties, ${ }^{104}$ Monistic traditions do not draw a bright line distinction between domestic and international law. ${ }^{105}$ This is due in part to the fact that laws in civil law traditions have the same natural law source and are automatically incorporated into domestic law. ${ }^{106}$ Elaborating on the theme of incorporating international legal norms into national legal systems, one commentator, George Slyz, notes that "[m]onism views international and national law as part of a single legal corpus, with the various national legal systems being derived from the broader framework provided by international law."107 Therefore, within a monist framework, human rights norms are not only part of the Taiwanese legal order as local law, they may be superior to it. ${ }^{108}$ In this regard, since "no theoretical barrier exists to applying international law," 109 the Taiwan Act would bind the Taiwanese Legislature to the requirements of the ICCPR and ICESCR in enacting legislation. ${ }^{110}$ Furthermore, not only would the legislative and judicial branches ${ }^{111}$ be obliged to observe these human rights instruments, but presumably, the executive branch would be equally obliged to ensure the laws are carried out. ${ }^{112}$

The dualist view, however, holds that domestic courts may incorporate or reject international elements as they see necessary. ${ }^{113}$ Slyz notes that "a nation is responsible to other nations for carrying out mutual obligations, but each state determines the means and form by which it carries out its obligations."114 Therefore, dualist states are usually required to change domestic law because international law applies by virtue of the domestic law's recognition and incorporation of such rules only. ${ }^{115}$ The international law is thereby transformed into domestic law and avoids any question of supremacy. ${ }^{116}$ Since Taiwan is of a civil law tradition, it should grant a higher normative status to human rights treaties like the ICCPR and ICESCR. ${ }^{117}$

If there was any debate as to whether Taiwan utilizes the concepts of

104. Waters, supra note 74 , at 641 .

105. Id.

106. Id.

107. George Slyz, Note, International Law in National Courts, 28 N.Y.U. J. INT'L L. \& PoL. 65, 67 (1996) (emphasis added).

108. Id.

109. Id.

110. Id.

111. "The central government consists of the Office of the President and five branches, or yuan-the Executive Yuan, the Legislative Yuan, the Judicial Yuan 司法院, the Examination Yuan 考試院 and the Control Yuan.” The Republic of China Yearbook 2010, Gov'T INFO. OFFICE 61, available at http://www.gio.gov.tw/taiwan-website/5-gp/yearbook/ 04Government.pdf.

112. Slyz, supra note 107 , at 67 .

113. Coyle, supra note 71 , at 656, n.1.

114. Slyz, supra note 107 , at 67.

115. Id.

116. Id. at 67-68.

117. Waters, supra note 74 , at 641 . 
monism or dualism, it should be dispelled by a plain reading of Article 2 of the Taiwan Act. Article 2 states that the "[h] uman rights protection provisions in the two Covenants have domestic legal status," 118 meaning Taiwan "avoids any question of the supremacy of one system of law over the other" regardless. Both concepts legitimize the application of international human rights instruments to Taiwanese domestic law. Therefore, looking forward, the Taiwanese legislature should be bound by the Covenants in enacting legislation; no barrier exists to applying international law into domestic legislation.

\section{MEANING AND IMPLICATIONS OF RATIFICATION AND NON- MEMBERSHIP OF AN INTERNATIONAL TREATY}

Taiwan's unique history "has trapped [its] inhabitants . . . in political purgatory. [T] he people of Taiwan have lived without any uniformly recognized government[, and i]n practical terms, this means they have uncertain status in the world community which infects the population's day-to-day lives."119 The existence of this political purgatory and the special status that arises from its ambiguity will almost certainly influence a non-State actor's participation in a treaty, mainly because it not clear whether a non-State can be a "party." Article 2 of the Vienna Convention on the Law of Treaties (VCLT) defines "party" as "a State which has consented to be bound by the treaty and for which the treaty is in force." 120 A plain reading of the VCLT indicates that a "party" must be a "State." 121 With regard to whether an entity would be entitled "State" status, Article 1 of the Montevideo Convention on the Rights and Duties of States provides, albeit somewhat oversimplified, that "[t]he state as a person of international law should possess the following qualifications: a) a permanent population; b) a defined territory; c) government; and d) capacity to enter into relations with the other states." 122 Although Taiwan is not recognized as a State, it may meet the requirements to be considered a "State" for purposes of a treaty. ${ }^{123}$ And since Taiwan has consented to be bound by the Covenants, it may be said that Taiwan is a kind of party to the Covenants, just not in the conventional sense. ${ }^{124}$

The VCLT also states that a treaty is an "international agreement

118. Taiwan Act, supra note 6, art. 2 .

119. Lin v. United States, 561 F.3d 502, 503 (D.C. Cir. 2009).

120. VCLT, supra note 79 , art. 2 , para. $1(\mathrm{~g})$.

121. See id.

122. Montevideo Convention on the Rights and Duties of States art. 1, Dec. 26, 1933, 165 L.N.T.S. 19 (1934). For perspectives on how the Montevideo Conventions may be imperfect, see Thomas D. Grant, Defining Statehood: The Montevideo Convention and Its Discontents, 37 COLUM. J. TRANSNAT'L L. 403 (1999).

123. See generally Tai-Heng Cheng, Why New States Accept Old Obligations, 2011 U. ILL. L. REV. 1, 47 (2011). The conventional view is that States do not need to be a member of the club to guarantee human rights. See infra note 132 and accompanying text.

124. See generally Tai-Heng Cheng, supra note 123. 
concluded between States in written form and governed by international law, whether embodied in a single instrument or in two or more related instruments and whatever its particular designation." ${ }^{125}$ Since Taiwan did not conclude the Covenants with other States, it cannot be said that the agreements, as recognized by Taiwan, are "treaties" in the traditional sense. But the VCLT goes on to say that "'ratification,' 'acceptance,' 'approval,' and 'accession' mean in each case the international act so named whereby a State establishes on the international plane its consent to be bound by a treaty.",126 Taiwan no doubt has expressed, through the Taiwan Act, its desire to implement (shishi) the Covenants. ${ }^{127}$ Implementation is an expression of an international act and suggests Taiwan's willingness and consent to be bound by the Covenants on an international level. Furthermore, by declaring that "[a]ll laws, regulations, directions and administrative measures incompatible to the two Covenants should be amended within two years after the Act enters into force by new laws, law amendments, law abolitions and improved administrative measures," Taiwan accepts that domestic laws, regulations, directions, and administrative measures should be compatible with the Covenants and that it has consented to be bound domestically, and arguably internationally, by their provisions. ${ }^{128}$

\section{A. Participant Discontent of the Exclusion of Parties}

The biased nature of Covenant membership has narrowed the participation of certain parties, causing twelve Member States to each make declarations upon signature of the ICCPR and ICESCR. ${ }^{129}$ In essence, these declarations recognize the discriminatory and limiting nature of Article 48 of the ICCPR and Article 26 of the ICESCR. ${ }^{130}$ Article 48 of the ICCPR, which is similar to Article 26 of the ICESCR, states that

[t] he present Covenant is open for signature by any State Member of the United Nations or member of any of its specialized agencies, by any State Party to the Statute of the International Court of Justice, and by any other State which has been invited by the General Assembly of the United

125. VCLT, supra note 79 , art. 2, para. 1(a).

126. Id. para. 1(b) (emphasis added).

127. Taiwan Act, supra note 6, art. 1.

128. Id. art. 8.

129. International Covenant on Civil and Political Rights, Declarations and Reservations, Dec. 16, 1966, 999 U.N.T.S. 171 [hereinafter Declaration]. The States are the Russian Federation, Romania, Guinea, Afghanistan, Bulgaria, Hungary, Mongolia, Syrian Arab Republic, Vietnam, and Ukraine. Id.

130. See, e.g., infra note 132 . 
Nations to become a Party to the present Covenant. ${ }^{131}$

The Russian Federation made the following declaration regarding Article 48 and Article 26:

The Union of Soviet Socialist Republics declares that the provisions of paragraph 1 of article 26 of the International Covenant on Economic, Social and Cultural Rights and of paragraph 1 of article 48 of the International Covenant on Civil and Political Rights, under which a number of States cannot become parties to these Covenants, are of a discriminatory nature and considers that the Covenants, in accordance with the principle of sovereign equality of States, should be open for participation by all States concerned without any discrimination or limitation. ${ }^{132}$

This declaration recognizes that, with regard to human rights treaties, all States should be allowed to participate. ${ }^{133}$ The spirit of the declaration also could support the conclusion that all territories or non-State actors should be granted participation as well. ${ }^{134}$ The conventional wisdom is that "the promotion and encouragement of respect for human rights and fundamental freedoms is an undertaking to be carried out for all." $" 135$ To this end, issues of human rights, arguably, should not be confused with issues of politics concerning sovereignty. $^{136}$

Although it did not sign the Covenants with other States parties, Taiwan should realize that by implementing the Covenants it is bound by their provisions and that it has opened itself up to international scrutiny. ${ }^{137}$ Through both domestic and international scrutiny, Taiwan will have more types of human rights enforcement than would be possible with its domestic legislation alone. ${ }^{138}$ As a non-State actor, Taiwan should be able to freely implement the Covenants into its domestic law, and at the same time, the international community should recognize and respect this implementation.

131. ICCPR, supra note 4 , art. 48 , para. 1 (emphasis added).

132. Declaration, supra note 129 (emphasis added).

133. See id.

134. See id.

135. Manual, supra note 11, at 4.

136. See Boyd, supra note 16 .

137. The author of this Note is of the opinion that scrutiny has been largely domestic, but for examples of international scrutiny, see SHIRLEY A. KAN, DEMOCRATIC REFORMS IN TAIWAN: ISSUES FOR CONGRESS (2010); Jerome A. Cohen \& Yu-Jie Chen, Jerome A. Cohen and Yu-Jie Chen on Taiwan's Incorporation of the ICCPR and ICESCR into Domestic Law, U.S. ASIA L. INST. (May 29, 2009), http://www.usasialaw.org/?p=1 142.

138. Tom Ginsburg et al., Commitment and Diffusion: How and Why National Constitutions Incorporate International Law, 2008 U. ILL. L. REV. 201, 215-16 (2008). 


\section{B. Validating Alterations in Domestic Law through Human Rights Law Mechanisms}

The Constitutional Court is charged with interpreting the Constitution of Taiwan, ${ }^{139}$ and it has historically incorporated international human rights laws into interpretations as a kind of "benchmark for domestic legal change." Interpretation No. $549^{141}$ and Interpretation No. $578^{142}$ advise the government to "overhaul the entire statutory regime with relevant international labor conventions." ${ }^{143}$ There, the Justices were urging the government to alter domestic law so that it observes international law. ${ }^{144}$ Alterations in domestic law may be similarly justified by the Taiwan Act. Article 8 states,

All levels of governmental institutions and agencies should review laws, regulations, directions and administrative measures within their functions according to the two Covenants. All laws . . . incompatible to the two Covenants should be amended within two years after the Act enters into force by new [or abolished] laws. ${ }^{145}$

The Human Rights Committee's General Comment 31 expresses the comprehensiveness of implementation required by the ICCPR and acts as a reminder to the State that the provisions of that Covenant should not be taken lightly. ${ }^{146}$ All branches of government must take responsibility, and any one branch cannot excuse itself of a violation by pointing to another. ${ }^{147}$

Even though Taiwan, through Article 8 of the Taiwan Act, has affirmatively committed to amend or abolish laws incompatible with Covenant rights within two years, its commitment to conformity is already implicit in the ICCPR. ${ }^{148}$ General Comment 31 states that States parties must take the

139. Minguo XiANFA art. 78 (1947) (Taiwan).

140. Chang, supra note 8 , at 216.

141. J.Y. Interpretation No. 549 (Aug. 2, 2002).

142. J.Y. Interpretation No. 578 (May 21, 2004).

143. Chang, supra note 8 , at 218.

144. Id.

145. Taiwan Act, supra note 6, art. 8.

146. See Human Rights Comm., General Comment No. 31: The Nature of the General Legal Obligation Imposed on States Parties to the Covenant, para. 3, 80th Sess. (2004), U.N. Doc. HRI/GEN/1/Rev.9 (Vol. I) (2008) [hereinafter General Comment No. 31]. "Pursuant to the principle articulated in article 26 of the Vienna Convention on the Law of Treaties, States Parties are required to give effect to the obligations under the Covenant in good faith." Id.

147. See id. para. 7. "Article 2 requires that States Parties adopt legislative, judicial, administrative, educative and other appropriate measures in order to fulfill their legal obligations. The Committee believes that it is important to raise levels of awareness about the Covenant not only among public officials and State agents but also among the population at large." Id.

148. Taiwan Act, supra note 6, art. 8. 
necessary measures "to give effect to the Covenant rights in the domestic order." ${ }^{149}$ In this regard, both the judiciary and the legislature have given the green light to alter Taiwan's domestic law to achieve conformity with the Covenants. ${ }^{150}$

\section{STATE REPORTING PROCESS}

The nine articles of the Taiwan Act no doubt were implemented to strengthen Taiwan's human rights protection system. ${ }^{151}$ But a government's responsibilities towards its domestic population do not end with implementation alone; each State is required to engage in a comprehensive campaign to see that every Covenant obligation is addressed. ${ }^{152}$ As such, it is crucial for States to have a correct and comprehensive understanding of the object and purpose of the Covenants as well as an accurate grasp of the scope and meaning of the obligations they create. ${ }^{153}$

How the Covenant provisions can be implemented in the domestic legal system has proven to be an ongoing learning process for both Taiwan's government and its civil actors. ${ }^{154}$ Through an initial reporting process, however, Taiwan may learn how to further implement and realize these human rights guarantees. ${ }^{155}$ Implementation in the domestic legal system and the concurrent reporting process represent just the birth of the Covenants, which will continue far beyond the administration that initiated the process. Indeed, "[a]ll politicians face problems committing to their promises," so the policies of

149. General Comment No. 31, supra note 146, para. 13. "Article 2 allows a State Party to pursue this in accordance with its own domestic constitutional structure and accordingly does not require that the Covenant be directly applicable in the courts, by incorporation of the Covenant into national law. The Committee takes the view, however, that Covenant guarantees may receive enhanced protection in those States where the Covenant is automatically or through specific incorporation part of the domestic legal order." Id.

150. Although comment 31 only discusses the ICCPR, similar arguments may be made for the ICESCR.

151. Taiwan Act, supra note 6, art. 1 ("This Act is made ... to strengthen our country's human rights protection system."). See also id. arts. 2-9.

152. For one perspective on the current state of implementation, see Vincent $Y$. Chao, Human Rights Day: Little Action on UN Human Rights Covenants: NGOs, TAIPEI TIMES (Dec. 11, 2010), http://www.taipeitimes.com/News/taiwan/archives/2010/12/11/2003490659.

153. See generally PegGy BretT \& PATRick MutZenberg, UN Human Rights COMMITTEe Participation IN the RePORTING Process: Guidelines for NON GOVERnMental ORGANISATIONS (NGOs) (1st ed. 2008) [hereinafter GuIDELINES], available at http://ccprcentre.org/doc/CCPR/Handbook/full\%20version.pdf.

154. For one example of such plan, see Renquan Dabuzou Jihua (人權大步走計畫) [Human Rights Program of Action], MINISTRY OF JUSTICE, http://www.humanrights.moj.gov.tw/public/Attachment/151910551973.doc.

155. See generally GUIDELINES, supra note 153 ("The Committee has often emphasized that the drafting of State reports should be an opportunity to review the national legislation, as well as administrative rules and procedures."). 
one politician must live beyond his or her term of office. ${ }^{156}$ The domestic and international scrutiny that should result from Taiwan's implementation of the Covenant's will generate valuable performance information and engage domestic and international governance. This will create political consequences for politicians who do not live up to their promises, ${ }^{157}$ and ultimately enhance the quality of human rights for current and future generations. ${ }^{158}$

\section{A. Motivations for the Implementation of the ICCPR and ICESCR into Domestic Law}

Admittedly, there may be motivations for signing or implementing treaties into domestic law other than the mutual gain from cooperative activity. ${ }^{159}$

Governments form treaties to achieve mutual gains from coordinated or cooperative activity at the international level. Without such gains, there is no reason for governments to enter into treaties. This approach[, however,] ignores the domestic sources of government policy and, thereby, underemphasizes the impact of domestic lobbying and the structure of the domestic political system in foreign affairs. ${ }^{160}$

While international instruments indicate to the international community the positions of their ratifying parties, domestic lobbying and the influence on the domestic political system, with regard to domestic interactions, are also of importance. ${ }^{161}$ This interest-group lobbying approach may be a more applicable way of viewing Taiwan's implementation of the Covenants because Taiwan's international interaction is limited. ${ }^{162}$ Ultimately, international commitments have three functions: (1) creating information by "utilizing international monitors, beyond the reach of any domestic politician, to generate neutral and valuable information on performance"; (2) creating costs for future violations; and (3) shifting decision-making authority to international actors. ${ }^{163}$

156. Ginsburg, supra note 138, at 213.

157. Id. at 214-15.

158. See supra Part II.

159. Rachel Brewster, The Domestic Origins of International Agreements, 44 VA. J. INT'LL. $501,540(2004)$.

160. Id.

161. Oona A. Hathaway, Do Human Rights Treaties Make a Difference?, 111 YALE L.J. 1935, 1940-41 (2002).

162. Taiwan's unique situation makes it difficult for the government to interact with other Nations. See generally Eric Ting-Lun Huang, The Modern Concept of Sovereignty, Statehood and Recognition: A Case Study of Taiwan, 16 N.Y. INT'L L. REV. 99 (2003).

163. Ginsburg, supra note 138, at 214. 


\section{B. Reporting Obligations Under Article 40 of the ICCPR}

Taiwan recognizes the importance of reporting the implementation status of the Covenants. This is evident in Article 6 of the Taiwan Act, ${ }^{164}$ which states, "The government should set up human rights reports system in accordance with the two Covenants." ${ }^{\text {"165 }}$ Articles of the ICCPR regarding reporting include Article 40:

1. The States Parties to the present Covenant undertake to submit reports on the measures they have adopted which give effect to the rights recognized herein and on the progress made in the enjoyment of those rights:

(a) Within one year of the entry into force of the present Covenant for the States Parties concerned;

(b) Thereafter whenever the Committee so requests.

2. All reports shall be submitted to the Secretary-General of the United Nations, who shall transmit them to the Committee for consideration. Reports shall indicate the factors and difficulties, if any, affecting the implementation of the present Covenant.

3. The Secretary-General of the United Nations may, after consultation with the Committee, transmit to the specialized agencies concerned copies of such parts of the reports as may fall within their field of competence.

4. The Committee shall study the reports submitted by the States Parties to the present Covenant. It shall transmit its reports, and such general comments as it may consider appropriate, to the States Parties.

5. The States Parties to the present Covenant may submit to the Committee observations on any comments that may be made in accordance with paragraph 4 of this article. ${ }^{166}$

Notwithstanding the initial reporting requirements under ICCPR, Article 40, paragraph 1 section (a), this Note recommends that a review process be conducted in the fall of 2013, with the state submitting its initial report in the

164. See Taiwan Act, supra note 6, art. 6.

165. Id.

166. ICCPR, supra note 4 , art. 40 (emphasis added). 
summer of 2012. ${ }^{167}$ The Taiwan Act states that "[a]11 laws, regulations, directions and administrative measures incompatible to the two Covenants should be amended within two years after the Act enters into force by new laws, law amendments, law abolitions and improved administrative measures." 168 This gives Taiwan time to adjust laws incompatible with the ICCPR and to submit a comprehensive report. ${ }^{169}$ During the beginning of 2013, the ad hoc Human Rights Committee will have time to draft a List of Issues, to which the State will have time to respond. ${ }^{170}$ Additionally, NGOs will have time to respond to the State Report and the State's response to the List of Issues. ${ }^{171}$

Article 40 also states that reports should be submitted to the SecretaryGeneral of the UN, who in turn should transmit them to the specialized UN agencies; the Secretary-General should also transmit the comments of the Committee to the Economic and Social Council. ${ }^{172}$ It is impossible for Taiwan to fulfill these procedural aspects because of its non-membership. Nonetheless, Taiwan should take responsibility for submitting a report to a neutral Committee. ${ }^{173}$

\section{Reporting Obligations Under Article 16 of the ICESCR}

The CESCR notes that, "in accordance with the letter and spirit of the [ICESCR], the processes of preparation and submission of reports by States

167. See infra Figure 1.

168. Taiwan Act, supra note 6, art. 8. The Presidential Office Human Rights Consultative Committee was established to "formulate human rights policies and review the nation's annual human rights reports." News Release, Office of the President, President Ma and Vice President Siew Attend First Meeting of the Presidential Office Human Rights Consultative Committee, (Dec. 10, 2010), [hereinafter Consultative Committee], available at http://english.president.gov.tw/Default.aspx?tabid=491\&itemid=23067\& $\mathrm{rmid}=2355$. The President of Taiwan has set up The Presidential Office Human Rights Consultative Committee to address these issues. Id.

169. It also takes into account the time Taiwan has given itself to make changes to domestic law. See David Sloss, The Domestication of International Human Rights: Non-Self-Executing Declarations and Human Rights Treaties, 24 YALE J. INT'L L. 129, 149-52 (1999) (discussing different domestic applications of international human rights treaties).

170. See infra Figures 1, 2.

171. Id.

172. ICCPR, supra note 4 , art. 40 , paras. $2-3$.

173. The Human Rights Committee reminds States parties that they "have undertaken to submit reports in accordance with article 40 of the Covenant within one year of its entry into force for the States parties concerned and, thereafter, whenever the Committee so requests." Human Rights Comm., General Comment No. 30: Reporting Obligations of States Under Article 40 of the Covenant, para. 1, 75th Sess., CCPR/C/21/Rev.2/Add.12 (2002), reprinted in Compilation of General Comments and General Recommendations Adopted by Human Rights Treaty Bodies, p. 242, U.N. Doc. HRI/GEN/1/Rev.9 (Vol. I) (May 27, 2008) [hereinafter General Comments]. 
can, and indeed should, serve to achieve a variety of objectives."174 The first objective recognizes the importance of the initial report so as to "ensure that a comprehensive review is undertaken with respect to national legislation, administrative rules and procedures, and practices in an effort to ensure the fullest possible conformity with the Covenant." 175 This spirit of reporting is much like that expressed in the ICCPR. ${ }^{176}$

Like the ICCPR, and notwithstanding the initial reporting requirements under Article 16 of the ICESCR, ${ }^{177}$ this Note recommends that a review process should occur in the fall of 2013, with the state submitting its initial report in the summer of 2012. ${ }^{178}$ Again, the two-year timeframe for compatibility under the Taiwan Act ${ }^{179}$ will allow Taiwan to adjust its incompatible laws and to submit a comprehensive report. ${ }^{180}$ The ad hoc CESCR will have time to draft a List of Issues during the beginning of 2013, and the State and NGOs will have time to respond accordingly. ${ }^{181}$

All reports will ultimately go to ad hoc committees for review. ${ }^{182}$ Since the Covenant prohibits members of the state being reviewed from serving as committee members, it would be beneficial for Taiwan to cooperate with other national governments and international NGOs to develop these ad hoc committees. ${ }^{183}$ The ad hoc Human Rights Committee and the ad hoc CESCR

174. Comm. on Econ., Soc. \& Cultural Rights [CESCR], General Comment No. 1: Reporting by States Parties, para. 1, 3rd Sess., U.N. Doc. E/1989/22, annex III at 87 (1989) [hereinafter CESCR General Comment No. 1], reprinted in General Comments, supra note 173, p.1-2. The Committee specifically notes seven objectives in their comment. Id. paras. 2-9.

175. Id. para. 2 ("Such a review might, for example, be undertaken in conjunction with each of the relevant national ministries or other authorities responsible for policy-making and implementation in the different fields covered by the Covenant.").

176. See supra Part V.B.

177. "The States Parties to the present Covenant undertake to submit in conformity with this part of the Covenant reports on the measures which they have adopted and the progress made in achieving the observance of the rights recognized herein." ICESCR, supra note 5, art. 16(1). "All reports shall be submitted to the Secretary-General of the United Nations, who shall transmit copies to the Economic and Social Council for consideration in accordance with the provisions of the present Covenant. Id. art. 16(2)(a). "The Secretary-General of the United Nations shall also transmit to the specialized agencies copies of the reports, or any relevant parts therefrom, from States Parties to the present Covenant which are also members of these specialized agencies in so far as these reports, or parts therefrom, relate to any matters which fall within the responsibilities of the said agencies in accordance with their constitutional instruments." Id. art. 16(2)(b).

178. See infra Figure 1.

179. Taiwan Act, supra note 6, art. 8.

180. See infra Figure 1.

181. See infra Figures 1, 2.

182. See infra Part VI.

183. Id. 
may be separate committees or combined into one; ${ }^{184}$ one committee may be a more practical option, but the concluding observations will likely be more fruitful if the committees are separate.

\section{ICCPR and ICESCR Reporting Process}

Generally, State Reports are divided into two parts. ${ }^{185}$ The first describes basic information about the reporting State, such as its land and people, general political structure, general legal framework within which human rights are protected, and information and publicity used to promote human rights awareness. ${ }^{186}$ The second part describes measures the State has taken to implement the specific provisions of the Covenants and should, as a rule, address every relevant substantive article. ${ }^{187}$ The remainder of this Note uses the terms "State Report" and "NGO report" when referring to the reporting process as it relates to the ICCPR ${ }^{188}$ Although the specific reporting processes under the ICCPR and ICESCR are slightly different, these ICCPR concepts can easily be translated to the reporting requirements of the ICESCR. ${ }^{189}$

\section{Initial State Report}

According to the Commission for Human Rights' Manual on Human Rights Reporting Under Six Major International Human rights Instruments, the second part of the initial report, which is important for Taiwan and its implementation process, should contain the following with regard to each article:

(a) The legislative, administrative or other measures in force in regard to each right;

(b) Any restrictions or limitations, even of a temporary nature, imposed by law or practice or any other manner on the enjoyment of the right;

184. See Caroline Dommen, The UN Human Rights Regime: Is it Effective?, 91 AM. SoC'Y INT'L L. PROC. 460, 483 (1997) (discussing the possibility of consolidation of human rights treaty bodies).

185. Manual, supra note 11, at 59-61.

186. Id.

187. Id. at 173. See also infra note 190 and accompanying text.

188. For an in depth explanation of the reporting process for The International Covenant on Civil and Political Rights, The International Covenant on Economic, Social and Cultural Rights, The International Convention on the Elimination of All Forms of Racial Discrimination, The Convention on the Elimination of All Forms of Discrimination Against Women, The Convention Against Torture and Other Cruel, Inhuman or Degrading Treatment or Punishment, and The Convention on the Rights of the Child, see Manual, supra note 11.

189. Id. 
(c) Any other factors or difficulties affecting the enjoyment of the right by persons within the jurisdiction of the State, including any factors affecting the equal enjoyment by women of that right;

(d) Any other information on the progress made in the enjoyment of the right.

The report should be accompanied by copies of the principal legislative and other texts referred to in the report. ${ }^{190}$

The Human Rights Committee has emphasized that "[i]t is of critical importance that States ensure that they describe the factual situation, or, in other words, the practical realities regarding the implementation and enjoyment of Covenant rights, rather than limiting themselves to a description of the formal situation as represented in the State's laws and policies." the legal norms should be described and elaborated, but the practical availability of remedies for violations of the ICCPR is equally important. ${ }^{192}$ Taiwan will need to report its principal legislative measures as well as other non-legislative or judicial measures it has taken to ensure the enjoyment of Covenant rights. ${ }^{193}$

In its Consolidated Guidelines for State Reports under the ICCPR, the Human Rights Committee emphasizes that it is particularly important for a State party to explain how Article 2 of the Covenant is applied. ${ }^{194}$ Article 2 includes the following two provisions:

1. Each State Party to the present Covenant undertakes to respect and to ensure to all individuals within its territory and subject to its jurisdiction the rights recognized in the present Covenant, without distinction of any kind, such as race, colour, sex, language, religion, political or other opinion, national or social origin, property, birth or other status.

2. Where not already provided for by existing legislative or

190. Manual, supra note 11 , at 174.

191. Factsheet No. 30, supra note 35, at 16.

192. See U.N. Secretary-General, Compilation of Guidelines on the Form and Content of Reports to be Submitted by States Parties to the International Human Rights Treaties, ch. III, sec. D.2.1, U.N. Doc. HRI/GEN/2/Rev.6 (June 3, 2009) [hereinafter Compilation of Guidelines].

193. See id.

194. U.N. Human Rights Comm., Consolidated Guidelines for State Reports Under the International Covenant on Civil and Political Rights, sec. D.2.2, U.N. Doc. CCPR/C/66/GUI/Rev.2 (Feb. 26, 2001). 
other measures, each State Party to the present Covenant undertakes to take the necessary steps, in accordance with its constitutional processes and with the provisions of the present Covenant, to adopt such laws or other measures as may be necessary to give effect to the rights recognized in the present Covenant. ${ }^{195}$

Article 2 also includes the availability of remedies for violations of the ICCPR.${ }^{196}$ Given the requirements set forth by the Human Rights Committee, Taiwan will need to address how its government will ensure to all individuals the rights recognized in the ICCPR, to what extent the laws or measures give effect to those rights, and what remedies are available for their violations. ${ }^{197}$

\section{Response to the list of issues generated by the ad hoc committee}

In the case of reporting under the ICESCR, a working group is established for each State. ${ }^{198}$ This working group is "to identify in advance the questions that will constitute the principal focus of the dialogue with the representatives of the reporting States. ${ }^{, 199}$ The Human Rights Committee asks each State party to provide in writing its replies to the lists of issues, far enough in advance of the reporting session so as to enable the replies to be made available to the Committee. ${ }^{200}$ These replies also should be timed so that NGOs will have a chance to comment on their content. ${ }^{201}$ As explained above, this Note recommends that a review process should happen in the fall of 2013, with the state submitting its initial report in the summer of 2012. ${ }^{202}$ This timeframe gives Taiwan time to amend or abolish laws incompatible with the ICESCR (and the ICCPR) and submit a comprehensive report. ${ }^{203}$ It also leaves time for the ad hoc committees to draft a List of Issues during the beginning of 2013 and allows the State time to respond to that list. ${ }^{204}$ Additionally, NGOs will have time to respond to the State Report and the State's response to the List of

195. ICCPR, supra note 4, art. 2, paras. 1-2 (emphasis added).

196. Id. art. 2. para. 3; see Compilation of Guidelines, supra note 192, ch. III, sec. D.2.1.

197. This list is not comprehensive and should be expanded along with national NGO participation. For a discussion regarding highly effective NGOs, see George E. Edwards, Assessing the Effectiveness of Human Rights Non-Governmental Organizations (NGOs) From the Birth of the United Nations to the 21 st Century: Ten Attributes of Highly Successful Human Rights NGOs, 18 MiCH. ST. J. INT'L L. 165 (2010).

198. CESCR, Working Methods, OHCHR.ORG, http://www2.ohchr.org/english/bodies/cescr/ workingmethods.htm (last visited Jan. 14, 2012).

199. Id.

200. Manual, supra note 11 , at 163.

201. See generally GUIDELINES, supra note 153.

202. See infra Figure 1.

203. Id.

204. These committees may be combined. See infra Part VI. 
Issues. ${ }^{205}$ Below is a chart with the timeline for State reporting suggested above. $^{206}$

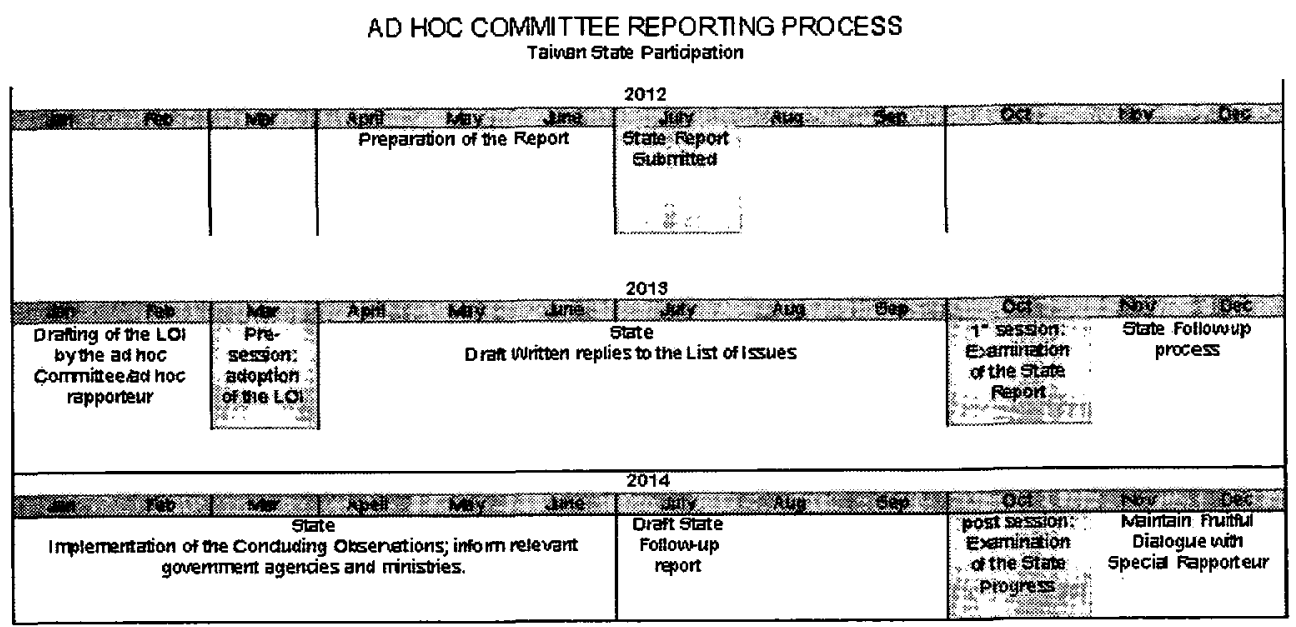

\section{NGO REPORTING PROCESS}

There is no doubt that NGOs have held an increasingly prominent role in the Covenant reporting process. ${ }^{207}$ The Human Rights Committee encourages NGOs to provide detailed, country-specific reports on States parties whose reports will be reviewed by the Committee. ${ }^{208}$ The Committee also invites NGOs to submit reports to the country task forces in charge of drafting the lists of issues. ${ }^{209}$ Breakfast or lunchtime briefings are often organized for the members of the Human Rights Committee so that NGOs can have a personal dialogue with and provide current information to the members. ${ }^{210}$ NGOs also are important once the concluding observations have been issued. ${ }^{211}$ Among the activities in which NGOs are engaged after the issuance of the concluding observations are reporting the steps taken by the government to the Human Rights Committee or CESCR, lobbying national government for the effective implementation of the concluding observations, and raising awareness about the

205. See infra Figure 2.

206. Figure 1 source: Author.

207. See Comm. on the Elim'n of Discrim'n Against Women [CEDAW], Statement by the Committee on the Elimination of Discrimination Against Women on its Relationship With Nongovernmental Organizations paras. 5-7, 45th Sess. (2010), available at http://www2.ohchr.org/english/bodies/cedaw/docs/statements/NGO.pdf.

208. Office of the U.N. High Comm'r for Human Rights, Report on the Working Methods of the Human Rights Treaty Bodies Relating to the State Party Reporting Process, para. 112, U.N. Doc. HRI/ICM/2010/2 (May 10, 2010).

209. Id.

210. Id. para. 117.

211. See generally GUIDELINES, supra note 153. 
concluding observations through media and other appropriate outlets. ${ }^{212}$ Therefore, at each step of the reporting process, it is important for NGOs to be actively involved in providing region-specific information. ${ }^{213}$ Taiwan has a number of national NGOs with the capacity to provide detailed reports to the ad hoc Human Rights Committee. ${ }^{214}$ These NGOs are capable of and should be pro-active in providing useful information in every aspect of the reporting process.

\section{A. Consulting NGOs}

As stated above, the Human Rights Committee welcomes NGO reports. ${ }^{215}$ In the case of Taiwan,

It is clear that NGOs and citizens have been pivotal in mediating international human rights and domestic constitutional/legal rights. In the course of their rights advocacies, they have taken commitments as well as responsibilities to make Taiwan into part of international human rights community and incorporating these international human rights laws firmly into the domestic legal soil. What these NGOs have built is not merely a domestic constitutional regime providing only domestic constitutional protections for individual rights. Rather, with their domestic/transnational natures of agency, they have built an intermediating transnational/constitutional regime where both international and domestic human rights laws meet with each other. ${ }^{216}$

The change has not been easy, but the following commitments by NGOs paved the way for greater progress in the area of human rights.

In the late 1980s NGOs began pushing for the enactment of the Convention on the Rights of the Child (CRC). ${ }^{217}$ These NGOs asked the government to formally recognize the $\mathrm{CRC}$ and to enact or revise domestic laws in accordance with its provisions. ${ }^{218}$ Their demands were heard, and the

212. Id. at 14-15.

213. See generally id.

214. Infra note 225. For detailed information regarding NGOs in Taiwan, see Ministry of Foreign Affairs, About NGO Affairs Committee, TAIWANNGo.Tw, http://www.taiwanngo.tw/english/about.asp (last visited Jan. 14, 2012).

215. See CEDAW, supra note 207.

216. Chang, supra note 8, at 229.

217. Chang, supra note 8 , at 222-23. Among these NGOs are the Garden of Hope Foundation, Taiwan Branch of the International Campaign to End Child Prostitution in Asian Tourism (ECPAT Taiwan), Taipei Women's Rescue Foundation (TWRF), and the Rainbow Project of the Presbyterian Church in Taiwan. Id. at n.59.

218. Chang, supra note 8 , at 222-23. 
Government of Taiwan amended its Child Welfare $\mathrm{Act}^{219}$ to reflect many of the CRC principles embodied. ${ }^{220}$ This ultimately led to full compliance with the CRC in $1993 .{ }^{221}$

[T] he CRC has since occupied a prominent normative status regarding rights of the child. In all subsequent legal processes, whenever relevant laws were to be made or amended, the CRC has been always referred to and even served as a firm ground for such legal change. Even the Constitutional Court referred to it twice in constitutional interpretations related to children's rights. ${ }^{222}$

In August 2004 numerous NGOs joined forces, forming a league for promoting the Convention on the Elimination of All Forms of Discrimination against Women (CEDAW). ${ }^{223}$ The League pressed the issue of CEDAW accession with the Government of Taiwan, and on January 5, 2007, the Legislative Yuan passed the accession. ${ }^{224}$ This NGO coalition was also key in lobbying the government for its initial state report, which was published in March 2009. ${ }^{225}$

The increased involvement of NGOs in lobbying the Taiwanese government to ratify these agreements should continue under the Taiwan Act. ${ }^{226}$ It is also highly important that Taiwanese NGOs be actively involved in providing relevant information regarding the Covenants. ${ }^{227}$

219. Ertong ji Shaonian Fuli yu Qianyi Baozhang Fa (兒童及少年福利與權盆保障法) [Children and Youth Welfare Act] (amended May 12, 2010) (Taiwan).

220. Chang, supra note 8 , at 222-23.

221. Id.

222. Id. See also Int'l Campaign to End Child Prostitution in Asian Tourism, [O]rigin and History, ECPAT TAIWAN, http://www.ecpat.org.tw/english/history.htm (last visited Jan. 14, 2012) (discussing issues relating to children's rights).

223. Chang, supra note 8, at 225. These included NATWA, the Awakening Foundation, the Taipei Chapter of the Awakening Foundation, Chang Fo-Chuan Center for the Study of Human Right, Human Rights Program Center at Soochow University, Women's Research Program Center at National Taiwan University, ECPAT Taiwan, Taiwan Women's Film Association, the Garden of Hope Foundation, and the Taiwanese Feminist Scholars Association. Id.

224. Id. at $226 \&$ n. 82

225. Id.

226. "These NGOs and citizens ... advocated much more strongly for treaty accessions as well as domestic statutory incorporation. Even after the attempts at accession failed, these NGOs continued pressing the government to voluntary compliance with the treaties and incorporation into domestic laws. In the course of their rights advocacies, these NGOs and citizens have become much more informed, more transnational in their knowledge and connections, and last but not the least, pivotal in mediating transnational /constitutional norms." $I d$. at 228 .

227. See generally GUIDELINES, supra note 153. 


\section{B. Follow-up Procedures and NGO Involvement}

Once the concluding observations have been issued, "[t]he [Human Rights] Committee may request the State party to give priority to such aspects of its concluding observations as it may specify."228 Regarding "such aspects," the Special Rapporteur for follow-up on concluding observations, Sir Nigel Rodley, has suggested:

Once the follow-up information has been received by the Special Rapporteur, he undertakes an assessment, with the assistance of the Secretariat, by carefully analysing whether all the recommendations of the Committee which were selected for follow-up have been addressed by the State party. Based on this assessment, the reply is classified as incomplete, partially incomplete or complete. Where information from non-governmental organizations is available, it is also taken into consideration in the Special Rapporteur's assessment. Currently, most follow-up information provided is classified as partially incomplete and, based on such finding, the Special Rapporteur sends a letter to the State party requesting additional information, detailing the exact information needed by the Committee. A draft letter is provided by the Secretariat. ${ }^{229}$

It is therefore important that NGOs are involved in the follow-up process, not only to fulfill reporting obligations but also to inform the public of Covenant challenges.

The Special Rapporteur classifies the State follow-up information according to the following five categories: (1) "Largely satisfactory," (2) "Cooperative but incomplete," (3) "Recommendation(s) not implemented," (4) "Receipt acknowledged," or (5) "No response." ${ }^{\text {"230 }}$ Basically, the Special Rapporteur should remain in contact with a State until the next periodic report is due, and that State's cooperation should be noted in the next concluding observations. ${ }^{231}$ NGOs should also maintain contact with the State and Special Rapporteur so they may provide relevant information to the public. Communications between the Special Rapporteur and the States parties are published on the High Commissioner for Human Rights website, and it is

228. U.N. Human Rights Comm., Rules of Procedure of the Human Rights Committee, R. 71(5), U.N. Doc. CCPR/C/3/Rev.8 (Sept. 5, 2005).

229. Paper of the Special Rapporteur for Follow-up on Concluding Observations: Strengthening of the Follow-up Procedure, para. 5, U.N. Doc. CCPR/C/CCPR/C/95/3 (July 2, 2009) (emphasis added).

230. Id. para. 32 .

231. See id. paras. 31,33 . 
important for NGOs to be aware of these communications and to transmit this information to the relevant authorities and media outlets. ${ }^{232}$ The website contains country specific information as well as follow-up information for all States parties. ${ }^{233}$ Equally as important, Taiwan must be aware of the communications of the ad hoc Rapporteur in order to aid in appropriate lobbying of relevant governmental bodies. ${ }^{234}$ The Government of Taiwan should maintain a similar website so that stakeholders may be aware of similarly relevant information.

Additionally, the UN Office in Geneva maintains a website that contains press releases and meeting summaries. ${ }^{235}$ These summaries are fairly comprehensive and are valuable for NGOs who cannot attend Human Rights Committee sessions. ${ }^{236}$ This Note suggests Taiwan have a similar media outlet so that NGOs and media outlets may stay current with issues during the reporting to the ad hoc committees. ${ }^{237}$ Below is a chart reflecting the suggested NGO reporting timeline. ${ }^{238}$

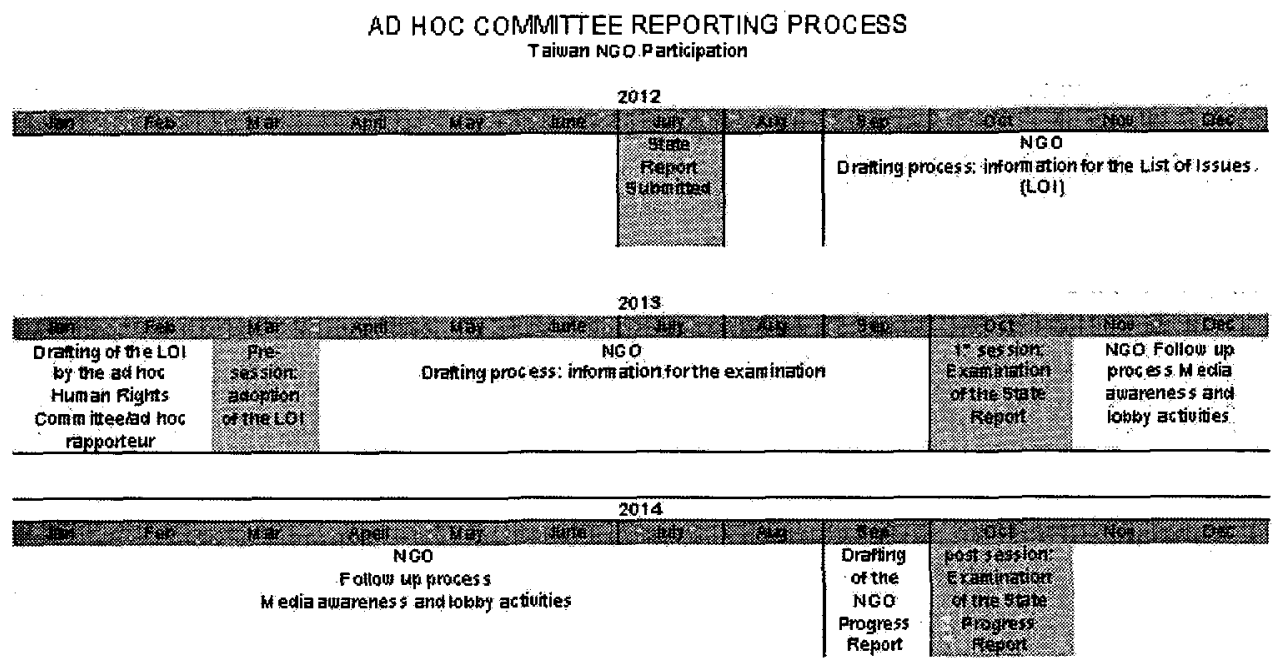

232. Id. para. 34 .

233. See Office of the High Comm'r for Human Rights, Human Rights Bodies, OHCHR.ORG, http://www.ohchr.org/EN/HRBodies/Pages/HumanRightsBodies.aspx (last visited Jan. 14, 2012).

234. Lobbying activities have been seen as an important means to ensure Covenant rights. See GUIDELINES, supra note 153, at 15.

235. See U.N. Office at Geneva, Press Releases \& Meeting Summaries, UNOG, http://www.unog.ch/80256EDD006B9C2E/\%28httpPages\%29/CBD301FF98AF69B980256EE 700376D86? OpenDocument\&count=10 (last visited Jan. 14, 2012).

236. See id.

237. Currently, a non-profit umbrella organization called "Covenants Watch" maintains updates on Covenant activities. See COVENANTS WATCH, http://covenants-watch.blogspot.com/ (last visited Jan. 14, 2012).

238. Figure 2 source: Author. 


\section{MAKEUP OF THE AD HOC COMMITTEE(S) $)^{239}$}

Articles 28 and 31 of the ICCPR refer to the composition of the Human Rights Committee. ${ }^{240}$ Article 28 states that the eighteen-member Committee "shall be persons of high moral character and recognized competence in the field of human rights, consideration being given to the usefulness of the participation of some persons having legal experience. ${ }^{, 241}$ In addition, Article 28 provides that Committee members serve in their personal capacity and not on behalf of a country. ${ }^{242}$ The Secretary-General of the UN invites States parties to submit nominations for Human Rights Committee membership. ${ }^{243}$ The Secretary-General then submits a list of the nominees to the current Committee for a vote. ${ }^{244}$ Article 31 states that "[ $\left.t\right]$ he Committee may not include more than one national of the same State" and, further, that "consideration shall be given to equitable geographical distribution of membership and to the representation of the different forms of civilization and of the principal legal systems."245

The UN Economic and Social Council (ECOSOC) created the CESCR to monitor ICESCR implementation by State parties. ${ }^{246}$ ECOSOC resolution $1985 / 17$ states that " $[\mathrm{t}]$ he Working Group established by [ECOSOC] decision 1978/10 and modified by Council decision 1981/158 and resolution 1982/33 shall be renamed "Committee on Economic, Social and Cultural Rights." 247 The renamed committee should have eighteen human rights experts elected for a term of four years ${ }^{248}$ by the Council from nominees submitted by States parties. ${ }^{249}$ Similar to the Human Rights Committee, the CESCR shall give due consideration "to equitable geographical distribution and to the representation

239. Ideally, there would be two committees - one for the ICCPR and one for the ICESCR. But see Dommen, supra note 184, at 483 ("What is needed, in my opinion, is the consolidation of the six committees into two bodies: one with power to review country reports under all six treaties, the other to deal with individual communications under the treaties that confer such jurisdiction.").

240. See ICCPR, supra note 4 , arts. 28,31 .

241. Id. art. 28 , para. 2.

242. Id. art. 28 , para. 3.

243. Id. art. 30, para. 2.

244. Id. art. 30, para. 3.

245. Id. art. 31 , paras. 1-2. Considering the requirements of article 31 , the so-called Presidential Office Human Rights Consultative Committee cannot be the body that reviews the implementation of the Covenants. This body is there to "implement the covenants" and not to oversee the review of the implementation. Consultative Committee, supra note 168.

246. U.N. Econ. \& Soc. Council Res. 1985/17, Review of the Composition, Organization and Administrative Arrangements of the Sessional Working Group of Governmental Experts on the Implementation of the International Covenant on Economic, Social and Cultural Rights, pmbl., para. a, 22nd plen. mtg., May 7-31, 1985, ECOSOC, Supp. No. 1, U.N. Doc. E/1985/85, at 15 (May 28, 1985).

247. Id.

248. Id. para. $\mathrm{c}(\mathrm{i})$.

249. Id. para. b. 
of different forms of social and legal systems." 250

For Taiwan, this Note recommends that an ad hoc coalition of both international and domestic academics and NGOs convene to prepare a list of nominees for one or more ad hoc committees. This list, along with the curricula vitae of nominated parties, should then be voted on by the ad hoc coalition, resulting in around twenty members for each ad hoc committee.

Rule 17 of the Rules of Procedure of the Human Rights Committee states that the "Committee shall elect from among its members a Chairperson, three Vice-Chairpersons and a Rapporteur." ${ }^{251}$ These officers are normally elected for a term of two years, but this Note recommends that the ad hoc committee officers be elected for four years to account for the time it will take Taiwan to go from initial report to follow-up report. ${ }^{252}$ The procedures also provide for Human Rights Committee appointed special rapporteurs. ${ }^{253}$ These rapporteurs may have the specific function of communications under the Optional Protocols, which does not apply to Taiwan. ${ }^{254}$ The third rapporteur is in charge of the follow-up to the Concluding Observations, which is crucial to the reporting process. ${ }^{255}$ Ultimately, Taiwan's ad hoc committee should mirror as much as possible the composition of the Human Rights Committee and the CESCR.

\section{A. Duty to Create and Importance of the Ad Hoc Committee(s)}

The purpose of the meeting with the reporting State is to "establish a constructive dialogue between the Committee and the State Party." The Human Rights Committee and the CESCR are neither judicial nor quasijudicial but are there to "assist States Parties in fulfilling their obligations under the Covenant, to make available to them the experience the committee has acquired in its examination of other reports and to discuss with them any issue related to the enjoyment of the rights enshrined in the Covenant. ${ }^{, 257}$ The ad hoc committee too should exist to engage representatives in fruitful dialogue. ${ }^{258}$

The Human Rights Committee has noted that its task is to "supervise and monitor the implementation of Covenant obligations by States parties." 259 Since the Committee is made up of actors from all over the world, there is no "single

250. Id. para c(ii).

251. U.N. Human Rights Comm., supra note 228, R.17.

252. Id. R.18.

253. Id. R.95(3).

254. Id. R.101.

255. Id. R.97.

256. Manual, supra note 11, at 262.

257. Id.

258. Id.

259. Office of the U.N. High Comm'r for Human Rights, Civil and Political Rights: The

Human Rights Committee 14, Fact Sheet No. 15 (May 2005), http://www.ohchr.org/Documents/Publications/FactSheet1 5rev.1en.pdf. 
geographical or national perspective, the Committee speaks with a global voice. ${ }^{, 260}$ Similarly, Taiwan should strive to have an ad hoc committee made up of international actors with specialties in human rights, ${ }^{261}$ the intent being to mirror, as much as possible, the philosophy of the Human Rights Committee and the CESCR. ${ }^{262}$

\section{B. Lessons from the CEDAW Ad Hoc Committee}

In Taiwan, the CEDAW was ratified by the Legislature and signed by the President in $2007 .{ }^{263}$ Professor Wen-Chen Chang notes that the accession "was passed by an overwhelming parliamentary majority ....264 The first official State CEDAW report was published in March 2009 and addressed the substantive articles in the Convention, including an overview of the island. ${ }^{265}$ Further, an international symposium was organized with the aim of having independent experts examine the reports, much like if a state were to submit its report to the CEDAW in Geneva. ${ }^{266}$ The three ex-CEDAW committee members were invited to this symposium and published their findings. ${ }^{267}$ Taiwan should use a similar approach but should include more committee members. ${ }^{268}$ As with the ad hoc committee's membership and philosophy, this Note recommends that Taiwan aim to mirror the procedure of the UN committees. ${ }^{269}$

260. Id.

261. This Note accepts that the current system of reporting to the UN is sufficient. But see Dommen, supra note 184, at 483 ("In short, the current UN treaty body system with its six committees, ranging in size from ten to twenty-three members, and a mandate calling for the administration of six human rights treaties with frequently overlapping human rights guarantees, is every day less able to discharge its responsibilities.").

262. Taiwan's previous experience with the CEDAW ad hoc committee was less than ideal; the Committee had only three members. See NAT'L AllianCE OF TAIWAN WOMEN's Assoc'NS, http://www.natwa.org.tw/ (last visited Jan. 14, 2012).

263. Id.

264. Id. at 221 .

265. Id.; Initial Report of Republic of China (Taiwan), CEDAW, (Mar. 25, 2009), available at http://www.womenweb.org.tw/doc/CEDAW_Initial_Report.pdf.

266. Chang, supra note 8 , at 226.

267. See Dr. Anamah Tan et al., Findings of the Taiwan CEDAW Committee, Found. WOMEN RTS. Promotion \& DEv. (Mar. 27, 2009), http://wrp.womenweb.org.tw/ Uploads/\%7B18F510E4-B8B8-4920-8F7D-12F8EE2189CE\%7D_ CEDAW\%E5\%BD\%99\%E6\%95\%B4NEW+\%E6\%A2\%9D\%E6\%96\%87.pdf.

268. Taiwan had three foreign experts, but the CEDAW is comprised of 23 experts. For a general discussion regarding the CEDAW committee, see Hanna Beate Schöpp-Schilling, Treaty Body Reform: The Case of the Committee on the Elimination of Discrimination Against Women, 7 HUM. RTS. L. REv. 201 (2007).

269. In addition, the Human Rights Committee has often emphasized the importance of civil society input. See GUIDELINES, supra note 153, at 12. 


\section{CONCLUDING REMARKS}

Before the Law stands a doorkeeper. To this doorkeeper there comes a man from the country who begs for admittance to the Law. But the doorkeeper says that he cannot admit the man at the moment. The man, on reflection, asks if he will be allowed, then, to enter later. "It is possible," answers the doorkeeper, "but not at this moment.",270

- Franz Kafka, Before the Law

Taiwan pays a high level of respect to the human rights of its citizens, and making its laws conform to higher human rights standards is at the forefront of judicial activity. ${ }^{271}$ The Constitutional Court notes that " $[t]$ he maintenance of personal dignity and the protection of personal safety are contained in the Universal Declaration of Human Rights, and are also two of the fundamental concepts underlying [Taiwan's] constitutional protection of the people's freedoms and rights."272 Referencing and incorporating international instruments in Taiwan is not a new concept. ${ }^{273}$ In a single Interpretation, the Constitutional Court reference the Sixth Amendment to the United States Constitution, Article 37-II of the Japanese Constitution, Article 304 of the Code of Criminal Procedure of Japan, Article 239 of the Code of Criminal Procedure of Germany, Article 6-III(iv) of the European Convention for the Protection of Human Rights and Fundamental Freedoms, and Article 14-III(e) of the International Covenant on Civil and Political Rights. ${ }^{274}$ Other Interpretations reference Article 5 of the European Convention for the Protection of Human Rights and Fundamental Freedom, Article 9 of the International Covenant on Civil and Political Rights, and Article 7 of the American Convention on Human Rights. ${ }^{275}$ Such references have helped legitimize international instruments in Taiwan's domestic legal system. ${ }^{276}$

Since Taiwan is of a civil law tradition, it should grant at least an equal normative status to human rights treaties like the ICCPR and ICESCR. ${ }^{277}$ There should be no "question of the supremacy of one system of law over the other" because each is "supreme in its own sphere.",278

But human rights law, indeed, may be superior to the Taiwanese legal

270. Franz Kafka, "Before the Law," The Trial, reprinted in LAW AND LITERATURE: TEXT AND THEORY 255 (Lenora Ledwon ed. 1996).

271. See History, JUD. REFORM Found, http://www.jrf.org.tw/newjrf/english.htm (last visited Jan. 14, 2012). The Judicial Reform Foundation "aims to reform and improve the judicial system." Id.

272. J.Y. Interpretation No. 372 (Feb. 24, 1995) (emphasis added).

273. See supra Part II.

274. J.Y. Interpretation No. 582 (July 23, 2004).

275. See, e.g., J.Y. Interpretation No. 392 (Dec. 22, 1995).

276. See supra note 139-50 and accompanying text.

277. Waters, supra note 74, at 641.

278. Slyz, supra note 107, at 68 . 
order. ${ }^{279}$ Since "no theoretical barrier exists to applying international law," 280 the Taiwanese legislature, through the Taiwan Act, should be bound by the requirements of the ICCPR and ICESCR in enacting legislation. ${ }^{281}$ The next four years are crucial for Taiwan to prove its commitment to the Covenants.

The incorporation of the ICCPR and ICESCR into domestic law has provided Taiwan with an exciting opportunity to hold itself accountable for human rights issues and to realize further protections of human rights already enjoyed to a large extent by Taiwanese citizens. ${ }^{282}$ This Note has legitimized Taiwan's domestic implementation of these international human rights instruments ${ }^{283}$ and has given suggestions for proper reporting procedures under each Covenant's mandate. ${ }^{284}$ Already, the commitments of Taiwan's Constitutional Court, legislature, NGOs, and stakeholders have been pivotal in imbedding international human rights norms into the domestic legal landscape. ${ }^{285}$ The formation of ad hoc committee(s) in conjunction with other foreign experts can facilitate a fruitful and constructive dialogue between these actors so that the human rights situation in Taiwan may become even stronger. ${ }^{286}$ The international community should, indeed must, respect this implementation and provide its honest scrutiny of the ongoing implementation of Covenant rights into Taiwanese domestic law.

279. Id. at 67-68.

280. Id.

281. Id.

282. For current information regarding the Covenants in Taiwan, see COVENANTS WATCH, supra note 238.

283. See supra Parts II, III.

284. See supra Parts IV, V.

285. Chang, supra note 8 , at 229.

286. See id. 